started research in physics, working in the Cavendish Laboratory with Lord Rutherford and Dr. (now Sir James) Chadwick. In 1934 he made the discovery of the capture of a neutron by a proton to form a deuterium nucleus with emission of gamma radiation. For this and related work he was elected to a fellow. ship at Trinity in 1934. He took the degree of Ph.D. (Cambridge) in 1935. Then he turned to biophysics, and went to work at the Strangeways Laboratory, first with a grant from the British Empire Cancer Campaign and then during 1942-46 as Prophit Student of the Royal College of Surgeons. His first work in this field was a study of the mechanism of the bactericidal action of radiations, made in conjunction with his friends Drs. R. B. Haines and C. A. Coulson, and was a promising beginning, with quantitative interpretation of the results in terms of the target theory. Although twenty-one out of his thirty-one biological papers were published in collaboration, it is evident that in many of them Lea made a major contribution both to the experimental technique and the quantitative interpretation. His experimental skill, developed during his period of training at the Cavendish Laboratory, is demonstrated in his papers on a radiation dosemeter and automatic devices for controlling the output of X-ray tubes, and the X-ray equipment he built at the Strangeways Laboratory. He went to great pains to learn the necessary biological techniques, as shown, for example, in his paper on the delayed lethal action of radiations on chick embryos.

Lea's outstanding contributions to radiobiology are to be found in his papers on the target theory of gene mutation, the variation with wave-length of the biological effects of radiations, the inactivation of viruses and enzymes by radiations and the mechanism of induction of chromosome aberrations by radiations. Of great interest and importance was his work in collaboration with Dr. D. G. Catcheside on chromosome aberrations in Tradescantia, in which was made the remarkable theoretical prediction, with experimental verification, of the sharp maximum in efficiency of chromatid breakage by soft X-rays at a wave-length between 4 and $5 \mathrm{~A}$.

During the last few years Lea was becoming increasingly interested in the mechanism of radiochemical reactions in relation to biological effects. In October 1946 he was appointed reader in radiobiology in the Department of Radiotherapeutics of the University of Cambridge, though on account of the shortage of laboratory space he continued to work at the Strangeways Laboratory. Only two days before his death he was informed that he had been successful in his application for the degree of Se.D. of the University of Cambridge. He had many plans, and had arranged to take leave of absence during the next academic year to work at the Memorial Hospital in New York.

Lea had come to occupy an exceptional position as collaborator, adviser and friend to a great many workers in a wide range of subjects requiring the application of biophysical, statistical and mathematical techniques. We all liked him for his unending kindness, his integrity, his modesty and his patient helpfulness. $\mathrm{He}$ always produced the information required, without considering time or trouble. It is very difficult to estimate the extent of his influence. Although it could be said that his work was his main interest, he was also essentially a family men, and greatly devoted to his wife and two young children. J. S. MITCHELI

\section{K. H. Stephensen}

AFrer a short illness from pneumonia Knud Hensch Stephensen, inspector of the University Zoological Museum of Copenhagen, died on March 13.

Stephensen was born on November 29,1882 , and took his degree as candidatus magisterii at the University of Copenhagen in 1907. Besides teaching at a grammar school, he at once embarked upon the study of crustaceans, which held his interest for the rest of his life. From 1914 he was curator of the crustacean collections of the University Zoological Museum and was thus the suecessor of H. J. Hansen and, before him, Henrik Kröyer ; under his care, the collections were kept in excellent order and grew considerably. At the same time he was a very productive investigator, the total number of his papers being about 130 ; practically all of them deal with crustaceans and pycnogonids.

Stephensen's work was primarily systematic and faunistic, and he seldom attempted to draw general conclusions of a higher order; but all his papers bear witness to his deep penetration into his subject ; he was a capable draughtsman, and had a thorough knowledge of the literature of the Crustacea. He dealt with almost all groups of the Malacostraca, and was one of the few systematicists left who really mastered this big group. But even he had to realize the necessity of specialization; and he chose one of the most difficult and largest groups, the amphipods. A long series of papers appeared on the North Atlantic species, benthonic as well as planktonic; big reports on the collections of the Ingolf and the Thor Expeditions were followed by papers on collections from almost every part of the world. At his death he was undoubtedly the leading authority on the systematics of amphipods. Yet one of his last papers-and an excellent one-was on the crabs of the Persian Gulf.

Stephensen led a happy life; he was enthusiastic about his work, whether sitting quietly at the microscope in the museum or collecting in the field. In 1912 he spent the summer in West Greenland studying the fauna of the fjords; during 1921-22 he took part in the Dana Expedition to the Sargasso Sea, West Indies and the Gulf of Panama, and in 1925 he collected in the Faroe Islands.

While his publications show him mainly as a carcinologist, Stephensen's general interests were wide; he was a keen all-round naturalist and also much interested in architecture and archæology. Many colleagues all over the world will miss his long and personal letters, written in his beautiful handwriting -colleagues who became his friends for life, if they happened to visit Copenhagen and once experienced the friendliness and hospitality of Stephensen and his wife.

Stephensen considered a sound taxonomy of fundamental importance to all branches of biology, ecology, physiology, etc., a view which has not been sufficiently appreciated by many working in these fields ; so much the greater was his pleasure when, in 1946, he was made a corresponding member of the Linnean Society of London, for he took it as a token that his work on the lines of Linnæus, whom he admired very much, had not been in vain.

Every empty chair in the field of zoological systematics is difficult to fill nowadays, and Stephen. sen's death means a great loss to Danish zoology; but his authority will be missed beyond the borders of his own country.

ANTON Fr. BruUN 